\title{
Factors Causes Students Low English Language Learning: A Case Study in the National University of Laos
}

Thongma Souriyavongsa (Corresponding author)

School of Educational Studies, Universiti Sains Malaysia, Malaysia

Tel: 601-6690-9027 E-mail: thongam_2008@yahoo.com

\begin{abstract}
Sam Rany
School of Educational Studies, Universiti Sains Malaysia, Malaysia

Tel:601-7506-3234 E-mail: sr11_edu045@student.usm.com
\end{abstract}

Mohamad Jafre Zainol Abidin

School of Educational Studies, Universiti Sains Malaysia, Malaysia

Tel: 601-9415-2105 E-mail: jafre@usm.my

Leong Lai Mei

School of Educational Studies, Universiti Sains Malaysia, Malaysia

Tel: 601-6454-1068Ｅ-mail: lmleong@usm.my

Received: December 6, 2012 Accepted: January 21, 2013 Published: January 22, 2013

doi:10.5296/ijele.v1i1.3100 URL: http://dx.doi.org/10.5296/ijele.v1i1.3100

\begin{abstract}
It has been generally well-known that most people faced some problems in learning English as a second or foreign language in non-English speaking countries; for example, in Lao People Democratic Republic (Lao PDR). This paper has a main purpose to explore students-teachers' weakness towards English language learning as a foreign language of a Continuing Summer Program for Bachelor's degree of Teacher Education in English at the
\end{abstract}




\section{Macrothink}

International Journal of English Language Education

ISSN 2325-0887 2013, Vol. 1, No. 1

Faculty of Education (FOE), the National University of Laos (NUOL) in Lao. A study focuses on the reasons that impact on their poor English performance. Data were drawn from the question "Why Lao students weak in English?". This question was administered to 30 English students-teachers in order to respond with their own views. Each respondent listed ten reasons that mentioned why students are poor in English language performance. Based on the findings of this research, main causes have been included namely: first, the majority of students stated that the English teachers are not well-trained; for instance, they use Lao language when teaching, so they cannot perform well to attract the interest of the student. Secondly, students lack of English foundation background. Third, students lack of confidence to use English because they are afraid of mistakes and shy feeling. Fourth, the curriculum is inappropriate for helping students to improve their English proficiency. Last but not least, English language is difficult to learn due to students are not well-motivated, encouraged and gained learning strategy. Furthermore, students do not practice speaking English with English native speakers, and class environment is crowded and noisy that is not fulfilled with teaching pedagogy.

Keywords: English language learning, factors, weakness 


\section{Introduction}

This paper has a main purpose to investigate the perception of English student-teachers who have registered in the Continuing Summer Program for Bachelor's degree of Teacher Education in English about the causes of students' poor performance in English language learning at the Faculty of Education (FOE), the National University of Laos (NUOL) in Lao PDR. This Program has been conducting during the school vacation. It offers a good opportunity for English teachers who had already graduated diploma certificate in the field of English program to further their studies in the same field. The duration of this program is three years, but students have to take time for two months for this extra-course annually. The program has been offered as a module depends on teachers' available times and teaching schedule during the semester opening.

Nevertheless, students generally are weak in English language learning were found in many parts of the world, especially for the countries that English is not spoken as the mother tongue. Hashemi (2011), identified that students' weakness in English language learning is due to the differences of social contexts, cultural environments; for example, in the environments where the first and second or foreign languages learning take place such as Cambodia, Laos, Thailand, Vietnam and others. English language has always played a key role in the Lao nation development, but the English proficiency level of Lao students is still far from satisfactory (Thang, Thing Siew, \& Nurjanah Mohd, 2011).

\subsection{Background}

English is not only use as an official language in many nations, but also influence on many different cultures in a large number of countries; it is the central language of communication in the world-wide (Susanna, 2007). It is clearly present when a lot of people in a country speak English as the first language such as in the United States of America, Canada, Britain, Australia, New Zealand, South Africa and others (Braine, 2005; crystal, 2006). The expansion of the English language has rapidly increased the needs to gain better communication English throughout the world because the aptitude to use English is very much needed for further studies, journeys in other countries as well as for social and professional global contacts of different kinds (Hashemi, 2011; Susanna, 2007). A study carried out by Ton \& Pham (2010), identify that the English language is generally used as an international language for communication among people from different language backgrounds in all parts of the world.

In the same vein, English language is a global language which can be used for communication with native-speakers and non-native-speakers in the worldwide, especially in the education section, all university students need it for their studies in order to search information and obtain knowledge; therefore, a lot of the universities throughout the world need to include English language as one of their educational tool requirements (Khader \& Mohammad, 2010). English is often used as the medium of instruction in higher education (Murray \& Christison, 2010). On the other hand, obviously the fact of the day-to day the process of teaching and learning of the English language also related to many interrelated with social and political uses (Ronald \& David, 2001). People's demands toward English in 
many countries in the world make English language is key factors and became the international language that spreads quickly (Carlo, 2012; Hessein, Demirok, \& Uzunboylu, 2009; Richards, 2001; Wozniak, 2010).

Lao PDR is one of the Asian countries that English language has been taught as a second or foreign language in schools and tertiary institutions; particularly, in higher education institutions. Laos used to be colonized by American and French for a long period of time. At that moment, the English language was limited use in Lao PDR because French was still largely used in official documents of the government as a medium of teaching and learning process in the most institutions of secondary and higher education levels as well as in running a business (Judy \& Luangpraseut, 1989). In general secondary school, students have studied English for two hours per week, which was not sufficient for English proficiency. Most students were not motivated to study English. Furthermore, all English documents were destroyed because the significance of this language was ignorant after Laos gained its independence from America in 1975 (Siphong, 2008).

In 1986, Lao PDR accepted a new way of thinking "Chintankan Mai" policy, representing a change from a centrally planned economy and an Eastern bloc-oriented foreign policy towards a market economy and an omnidirectional foreign policy because the carrying out of this policy influence a lot of Lao people towards the demand for English language learning (Souvannasy, Masashi, \& Yukiko, 2008a). Consequently, from 1980-1996, English gradually returned to important language due to Laos opened its door to the world in 1994. Lao government was offered such a large amount of official development support from many of international organizations. In 1997 Laos has also an opportunity to join the Association of South East Asian Nations (ASEAN), so English has become the first priority foreign language which needed in both the public and private sectors (Siphong, 2008).

John \& Ehow (2011), describes that nowadays, the English language has been introduced in the school curriculum from lower secondary school level as a compulsory course in 1997. Unfortunately, English is not currently officially taught in government primary schools (Siphong, 2008). Nevertheless, a study conducted by Judy \& Luangpraseut (1989), identified that for a long time, there were no obviously introduced goals for English programs in the Lao curriculum.

Many reasons that cause Lao students poor performance of their learning English as a foreign language such as the weakness of curriculum design, lack of English teachers, and lack of students' learning motivation. According to John \& Ehow (2011), stated that the problems of learning English language derived from many different factors in different environments such as school resources, class size, quality of teachers, and the school attendance of learners. Murray \& Christison (2010), observed that many students think English is only a school subject and they don't see its significance for their prospective employment to work with multinational or national companies where English is employed. Hutchinson \& Waters (1991); Susanna (2007), pointed out that the mismatch between the students' conceptual or cognitive capacities and the learners' English proficiency level often cause problems for students because the students' learning style and teachers' teaching approach do not match 
and also the English course does not relate to the students' needs and interests. Susanna (2007), also claimed that weak students usually have poor strategies and give up easily when they find struggle.

In addition, many studies have been conducted on students' poor performance in learning the English language such as a study of Challenges of Learning English in Australia towards Students Coming from Selected Southeast Asian Countries found that factors that affected the Asian students' weakness in learning English because of the changing of learners' habits, cultures, and the structure of languages; for example, there were no strict rules for pronunciation of their mother language (Cao, 2011). Besides, a survey into the causes of English language learning anxiety in students also found that students were afraid of making mistakes in the classes, failing the exams, as well as the poor socioeconomic background cause of the poor performance in learning languages (Khattak, Jamshed, Ahmad, \& Baig, 2011). While, a study of the determinants and issues in student achievement in English at the Lao secondary education level found that a majority of Lao secondary students have a problem with basic vocabulary skills which influence reading comprehension and the content of textbooks difficulty (Souvannasy et al., 2008a).

Hence, this paper investigates the determinants and issues of teaching and learning the English language as a foreign language or second language in Lao PDR: a case study in the National University of Laos, focus on the Faculty of Education students who have been taking the Continuing Summer Program for Bachelor of Teacher Education in English. In general aim of this study is to identify the problems and common discourses with the instructional implementation of English language in Laos. In doing so, this research also seeks to classify the factors that contribute to low English language proficiency among Lao students. What causes of the learners' poor performance in English language? Why are Lao students weak in English?

\section{Literature Review}

There are several of determinants and problems that effect to the students' learning English as a foreign or second language in a non-native speaking country as Lao PDR. Those factors may derive from many components including social environmental issues, the difference of culture, social economic extension, and etc. These issues cause students to have poor performance in language learning, particularly in the bottom billion countries such as Laos, Myanmar, Cambodia, and Vietnam. So, this paper has a main purpose to investigate the factors which contribute to students low English language proficiency.

\subsection{Causes of Weakness in English Language Learning}

The development in the quality of English language learning has not satisfaction towards the demands of the society in Laos. This is because of lack of several factors to support the learning and teaching approaches. According to Souvannasy, Masashi, \& Yukiko (2008b), identify that teaching and learning English implementation still has shortages of textbooks, unqualified English teachers and also unstandardized curriculum. The poor socioeconomic background is one of factors that creates learners face with the use foreign language (Khattak 
et al., 2011). A study has been conducted by (Muhammad, 2007), on the investigation of the factors that cause language anxiety for ESL/EFL learners in learning speaking skills and the influence it casts on communication in the target language found difficulties of language learning, differences in learners' and target language cultures, the difference in social status of the speakers are the factors that affect to the students' weakness of language learning. In addition, a study of problems encountered by Arab EFL learners showed that learners preferred to use Arabic rather than English for communication in both outside and inside the classroom, the lack of the target language exposure as spoken by its native speakers, the shortage and weakness of the contribution in their language teaching context, and lack of their personal motivation (Loae, 2011).

Normazidah, Koo, \& Hazita (2012); Trawiński (2005), also presented the factors that impact the EFL learners to have poor performance in English language learning as followings:

- English is regarded as a difficult subject to learn.

- Learners' learning depends on the English teachers as authorities.

- There is a lack of support to use English in the home environment and the community.

- Learners have insufficient or lacking of exposure to the language as there is a limited opportunity to use English outside the classrooms

- Students have a limitation of vocabulary proficiency as well as English reading materials are not always available.

- Learners have an unwillingness and lack of motivation to learn English as they do not see the immediate need to use the language.

- Lack of motivation for learning or the negative attitude towards the target language.

Chang (2010), indicated that reasons cause students' weakness for English language learning derived from learners' laziness, lack of efficiency of the school, and insufficient of parents' promotions. Moreover, according to Dembo (2004), specifies that time management is involved in students' educational achievement; for instance, students with better time-management skills tend to have higher grade-point average (GPA) than students with poorer time-management skills.Alderman (2004), states to the students' poor performance of language learning are affected from a lack of effort, lack of effective learning strategies, whereas a good language learner is a highly motivated students and a successful user of a large number of different strategies (Trawiński, 2005).So, teachers have to help them improve the motivational beliefs and language learning strategies in order to find ways that reach to their academic achievement.

Therefore, to these key factors, all stakeholders should find ways to solve the problems for learners' academic achievements.

\subsection{Motivation for English Language Learning}

In general, motivation is recognized as one of the most significant factors affecting students' 
performance of second language (L2) learning (Lei, 2012; Thang et al., 2011). At present, many numbers of Lao students have failed in their English language learning because of lack of motivation from some elements such as family background, social-environment, physical environment, culture, methods of learning and so forth (Dembo, 2004). Motivation can influence students' freedom, attention, attempt, patient, the frequency of using learning strategies, and their learning success (Zhou, 2012). Learners have pleasure for a second or foreign language learning when they receive motivation, especially internal motivation because it could be well predicted by perceived second language ability and independence (Wu, 2003).

For a long time, motivation is generally involved by English as foreign language teachers and researchers have been attempting to sustain students' motivation in learning English by knowing their English learning motivation types and factors which influence their supporting motivation in the long process of English learning is still in requirement of investigation in the Lao context (Lei, 2012). If students are strongly motivated, they will enjoy learning the language, need to learn the language and attempt to learn the language (Sakiroglu \& Dikilitas, 2012). Moreover, motivation has usually been considered to be the key concept in the learning of foreign language (Klimova, 2011).

\subsection{Learning Strategies}

Learning strategies are the methods that learners use to obtain information; normally high achievers learners use more learning strategies than do lower achieving learners (Dembo, 2004). There were several unsuccessful students in their study because they often failed to apply learning strategies appropriately to the task at hand. The aspects of researchers believe that learning strategies are as significant in second language acquisition (SLA) motivation; it provides the learners tools for gaining achieving the goal. They can facilitate specific aspects of the learner's competency such as communicative, and individual's emotional state that related to the learning process (Trawiński, 2005). It is very valuable to formulate and adapt learning strategies to complement learner's English language level and then encourage successful participation (Margaret, 2005). According to Ting (2009), students are able to overcome their weakness in some learning styles with suitable strategy training, and learning strategies can influence students' learning achievements. Moreover, learning strategic factors also enhance students to be good learners as Oxford (2001), classifies the characteristics of the good learners that $\mathrm{s} / \mathrm{he}$ :

- $\quad$ is an enthusiastic and accurate guesser;

- has a strong drive to communicate;

- $\quad$ is uninhabited and ready to make mistakes;

- emphasizes on form by looking at patterns and using analysis;

- take improvement of all practice opportunities;

- monitors his or her own speech and that of others; 
- $\quad$ pays attention to meaning

However, there are many scholars and researchers describe the difference of definitions of learning strategies as followings:

Richards \& Lockhart (2007), describe that learning strategies are the particular processes students use with individual learning tasks such as reading a chapter of a book or preparing a written summary of a passage as well as the student can select many different ways of completing the task, learners can make learning easier, faster, more enjoyable, more effective, and more transferable to new situations.

As highlighted by Grainger (2005); Oxford (2002), language learning strategies are conscious techniques for students' usage to purposely assist English language learning process which include both informal and formal interviews, group discussions, language learning diaries, dialogue journals among students and teachers, open-ended survey, structured three- or five point surveys of strategy frequency.

Ting (2009), describes that language learning strategies from a specific aspect as a) learning strategies are possible behavioral thus observable, or mental then not observable. b) Learning strategies could be either common methods or special action or techniques adopted to learn a target language. However, Ting also identifies that the term 'strategies' has been referred to as a small range of synonyms such as 'techniques, tactic, and skills, by which each expert or researcher defines their understandings in the particular field in quite different ways.

Abbasi, Ahmad, \& Khattak (2010), definite that language learning strategies are the specific manners or thoughts students use to increase their language learning.

\section{Methodology}

This paper aims to determine the problems and the practice of learning and teaching English as a foreign language in the Faculty of Education, the National University of Laos. However, the main objective of this study seeks to identify the factors that cause low English language proficiency among student-teachers who have registered in Continuing Summer Program for Bachelor of Teacher Education in English. There were 30 student-teachers who have enrolled in a Continuing Summer Program for Bachelor of Teacher Education in English, in the academic year 2011-2012, were entered into this study. The respondents were selected from two classes through the purposive sampling research method; each classroom was equally divided into 15 male and 15 female of English student-teachers. All participants were the second year students.

The question, "Why Lao students weak in English?," was employed as a tool in this study in order to ask the English student-teachers' perceptions towards reasons that Lao students are poor performance for learning English as a foreign language. All selected participants were asked to answer this question with individual aspects. Each person was required to give ten items which needed to write down in the blank A4 paper provided. The respondents' answerers were written in Lao language during their tutorials in the classes. After that all answers were returned back, the researcher identified and developed into categories for 
coding and categorizing constructing as well as each answer was also translated into English language. The data analysis was used Microsoft Excel for calculating in order to find percentage of each category that causes Lao students weak in English language learning factors.

\section{Findings}

The question "Why Lao students weak in English?" was employed as the research tool in this study has attempted to identify the possible factors that find during students' poor English performance learning. Table 1 below presents the factors that cause Lao students weak in English language learning. However, these cases cannot be generalized to all Lao students, but it does represent a majority of the learners; particularly, for student-teachers who have enrolled in Continuing Summer Program for Bachelor of Teacher Education in English in the academic year 2011-2012.

Though, the overall picture of the factors that affecting students' learning English language is discouraged and is indicative of the need to change the methods in which English language literacy is taught to Lao learners. According to Normazidah et al., (2012), specify that in learning English as a second language or a foreign language, research has established that it is the highest significant that learners receive utmost support in terms of supportive and conducive learning situation and adequate, meaningful language experience.

Therefore, the researcher would like to present factors that are currently affecting limited English proficiency at FOE, NUOL in the following table.

Table 1. Factors that affect limited English proficiency

\begin{tabular}{|c|c|c|c|}
\hline No & Category of Factors & Frequency & Percentages (\%) \\
\hline 1. & Family background influenced on using their English & & \\
\hline 2. & $\begin{array}{l}\text { language as everyday life communication. } \\
\text { Lack of English background knowledge. }\end{array}$ & $\begin{array}{l}11 \\
21\end{array}$ & $\begin{array}{l}36.7 \\
70.0\end{array}$ \\
\hline 3. & $\begin{array}{l}\text { The English teachers are not well trained, for example } \\
\text { using Lao language when teaching, so they cannot }\end{array}$ & & \\
\hline & perform well and influenced the interest of the students. & 23 & 76.7 \\
\hline 4. & $\begin{array}{l}\text { Students' lack of confidence to use the language because } \\
\text { they're afraid and shame when they make mistakes. }\end{array}$ & 16 & 53.3 \\
\hline 5 & The students feel that English is not important subject & & \\
\hline & because of their low expectation in education. & 14 & 46.7 \\
\hline 6. & $\begin{array}{l}\text { Old methods in teaching made the learning process dull } \\
\text { and not interesting, so students feel bored and lack of } \\
\text { interest. }\end{array}$ & 6 & 20.0 \\
\hline 7. & $\begin{array}{l}\text { The education system itself does not encourage the } \\
\text { students which means the resources such as textbooks, } \\
\text { library. }\end{array}$ & 10 & 33.3 \\
\hline 8. & Students not interested to read English books. & 6 & 20.3 \\
\hline 9. & $\begin{array}{l}\text { Students who came from rural areas less expose in using } \\
\text { the English language. }\end{array}$ & 3 & 10.0 \\
\hline 10. & Students are very poor in grammar usages. & 1 & 3.3 \\
\hline 11. & $\begin{array}{l}\text { Lao is not English language speaking country (English is } \\
\text { not Lao's mother tongue). }\end{array}$ & 9 & 30.3 \\
\hline
\end{tabular}




\begin{tabular}{llll}
\hline No & Category of Factors & Frequency & Percentages (\%) \\
\hline 12. & Lao's curriculum is not suitable for Lao students to help & & \\
& & 16 & 53.3 \\
them improve English. & 16 & 53.3 \\
13. & English language is difficult to learn. & 2 & 6.7 \\
15. Time is not enough for a tutorial. & 4 & 13.3 \\
16. & $\begin{array}{l}\text { Students themselves are not interested in study English. } \\
\text { native speakers. }\end{array}$ & \\
17. & The classroom is crowded, the environment is not & 12 & 46.7 \\
& suitable. & & 40.0 \\
18. & The constraint of financial resources supporting. & 5 & 16.7 \\
\hline
\end{tabular}

\section{Conclusion}

The main purpose of this study was to determine the factors that affect on students' English learning as a second language or a foreign language. According to the question, "why Lao students weak in English", was employed in this study in order to investigate the English student-teachers' perceptions towards their poor English language performance learning. The researcher analyzed the data and separated students' answers into 18 categories as the results in the table 1.

After analyzing the data through Microsoft Excel Program, the researcher can find the highlights that put forward valuable pedagogical implications in the learning and teaching of English language in Laos, especially in the FOE at NUOL.

1. The majority of students stated that the English teachers are not well trained, for example using Lao language when teaching, so they cannot perform well and influenced the interest of the students.

2. The majority of students' lack of English background knowledge; for example, the English curriculum is provided when they learn in the first year of low secondary school.

3. The majority of students lack of confidence to use the language because of afraid and feeling shame if they make mistakes; Lao curriculum is not suitable for Lao students to help them improve English; English language is difficult to learn.

4. Students do not practice to speak English with English native speakers; classroom is crowded as well as the environment is not suitable.

Therefore, the findings of this study clearly indicate that Lao students still have lack of many key factors to support them such as motivational encouragement, learning strategy and other related variables. In addition, this result also is highly important for language educations and policy makers to carefully inspect how language learning is theorized in Lao educational context and make necessary changes in order to both correspond to current the real life situations and advocate the best English language learning among Lao learners, particularly for higher education learners.

\section{Recommendation}

Given in English language learning factors that affect EFL learners can influence for language stakeholders try to find the ways to solve the problems. It is important that language 
instructors should recognize that such weakness is a main cause impact on students' English proficiency. Based on the results of this study, the following recommendations can be made in order to improve and facilitate the learners and teachers:

1. Students should be motivated to acquire a confidence whenever they make mistakes in language classrooms

2. Parents should try to encourage their children to actively involved in learning the English language at home and schools.

3. English teachers should equip well-training courses at the Faculty of Education, National University of Laos and abroad.

4. Students should be encouraged to practice English language with native speakers in both inside and outside classrooms.

5. The curriculum designers should think about the learners' needs in language learning when they plan to design curriculum.

6. Future research needs to continue to determine the pedagogical practices of learning and teaching in this country and at the same time, to evaluate and inspect the English teachers' qualifications and knowledge before allowing them to teach.

\section{Acknowledgements}

The researchers would like to take this opportunity to extend our gratitude to Vannasouk Baousangthong to help us collecting data and Sangsavanh Souriyavongsa uses her valuable time to write down Lao language and saves as a PDF file send to me. Moreover, the researchers have great thanks to all respondents who have been taking a Continuing Summer Program for Bachelor of Teacher Education in English to answer the questions.

\section{References}

Abbasi, M. G., Ahmad, A., \& Khattak, Z. I. (2010). Negative influence of large scale assessment on language learning strategies of the Secondary School Certificate (SSC) students. Procedia - Social and Behavioral Sciences, 2(2), 4938-4942. http://dx.doi.org/10.1016/j.sbspro.2010.03.799

Alderman, K. (2004). Motivation for Achievement: Possibilities for Teaching and Learning. Lawrence Erlbaum Associates.

Braine, G. (2005). Teaching English to the World: History, Curriculum, and Practice. Taylor $\&$ Francis.

Cao, T. N. (2011). The challenges of learning English in Australia towards students coming from selected Southeast Asian countries: Vietnam, Thailand and Indonesia. International Education Studies, 4(1), 13-20.

Carlo, M. (2012). Teaching English to Speakers of Other Languages. TESOL Journal, 6.

Chang, Y.-P. (2010). A Study of EFL college students' self-handicapping and English 
performance. Procedia - Social and Behavioral Sciences, 2(2), 2006-2010. http://dx.doi.org/10.1016/j.sbspro.2010.03.272

Crystal, D. (2006). English worldwide. In H. RICHARD, \& D. DAVID (Eds.), A History of the English Language. Cambridge University Press.

Dembo, M. H. (2004). Motivation and Learning Strategies for College Success: A Self-Management Approach. Lawrence Erlbaum Associates.

Grainger, P. (2005). Second language learning strategies and Japanese: Does orthography make a difference? System, 33(2), 327-339. http://dx.doi.org/10.1016/j.system. 2005.01.003

Hashemi, M. (2011). Language Stress And Anxiety Among The English Language Learners. Procedia - Social and Behavioral Sciences, 30(0), 1811-1816. http://dx.doi.org/10.1016/j.sbspro.2011.10.349

Hessein, G., Demirok, M. S., \& Uzunboylu, H. (2009). Undergraduate student's attitudes towards English language. Procedia - Social and Behavioral Sciences, 1(1), 431-433. http://dx.doi.org/10.1016/j.sbspro.2009.01.077

Hutchinson, T., \& Waters, A. (1991). English for Specific Purposes. Cambridge University Press.

John, L., \& Ehow, C. (2011). Factors Affecting quality of English language Teaching and Learning. $\quad$ Retrieved from http://www.ehow.com/info_8040040_factors-english-language-teaching-learning.html

Judy, L., \& Luangpraseut, K. (1989). Handbook for Teaching Lao-Speaking Students. Secramento, California: Southeast Asia Community Resource Center.

Khader, K. T., \& Mohammad, S. (2010). Reasons behind non-English major University Students' achievement gap in the English language in Gaza strip from students' perspectives Retrieved 26/09/2012 from http://www.qou.edu/english/conferences/firstNationalConference/pdfFiles/khaderKhader.pdf

Khattak, Z. I., Jamshed, T., Ahmad, A., \& Baig, M. N. (2011). An Investigation into the Causes of English Language Learning Anxiety in Students at AWKUM. Procedia - Social and Behavioral Sciences, 15(0), 1600-1604. http://dx.doi.org/10. 1016/ j.sbspro.2011.03.337

Klimova, B. F. (2011). Motivation for learning English at a university level. Procedia - Social and Behavioral Sciences, 15(0), 2599-2603. http://dx.doi.org/10.1016/ j.sbspro.2011.04.153

Lei, Z. (2012). Investigation into motivation types and influences on motivation: the case of Chinese non-English majors. English Language Teaching, 5(3), 100-122.

Loae, F. A. J. (2011). Problems encountered by Arab EFL learners. language in India, 11, $19-27$.

Margaret, B. (2005). Comprehension strategies for Englsih language learners. USA: Scholastic Inc. 
Muhammad, T. (2007). Investigation of the factors that cause language anxiety for ESL/EFL learners in learning speaking skills and the influence it casts on communication in the target language. Master of Education in English Language Teaching Pathway, University of Glasgow.

Murray, D. E., \& Christison, M. A. (2010). What English Language Teachers Need to Know: Understanding Learning. Taylor \& Francis.

Normazidah, C. M., Koo, Y. L., \& Hazita, A. (2012). Exploring English language learning and teaching in Malaysia. GEMA Online ${ }^{\mathrm{TM}}$ Journal of Language Studies, 12(1), 35-55.

Oxford, R. L. (2001). Language learning strategies. In C. Ronald, \& N. David (Eds.), The Cambridge Guide to Teaching English to Speakers of Other Languages. New York: Cambridge University Press.

Oxford, R. L. (2002). Language learning strategies in Nutshell: update and ESL suggestions. In J. C. Rechards, \& W. A. Renandya (Eds.), Methodology in language teaching. UK: Cambridge University Press.

Rechards, J. C., \& Lockhart, C. (2007). Reflective Teaching in Second Language Classrooms. United States of America: Cambridge University Press.

Richards, J. C. (2001). Curriculum Development in Language Teaching. New York: Cambridge University Press.

Ronald, C., \& David, N. (2001). The Cambridge guide to teaching English to speakers of other languages. New York: Cambridge University Press.

Sakiroglu, B., \& Dikilitas, K. (2012). Language Learning Motivation of Turkish Tertiary Level EFL Students. Procedia - Social and Behavioral Sciences, 46(0), 3215-3219. http://dx.doi.org/10.1016/j.sbspro.2012.06.039

Siphong, S. (2008). Developing students teachers' English learning strategies. In S. Gunnar (Ed.), Exploring Teacher Education in Laos-aims, obstacles and possibilities. Stocckholm: Stockholm University Press.

Souvannasy, B., Masashi, S., \& Yukiko, H. (2008a). Determinants and issues in student achievement in English at the Lao Secondary Education Level. In R. Paul, \& N. Roger (Eds.), The Asian EFL journal quarterly (Vol. 10). Korea: Paul Robertson.

Souvannasy, B., Masashi, S., \& Yukiko, H. (2008b). Determinants and issues in student achievement in English at the Lao Secondary Education Level. The Asian EFL Journal, 10(1), 48-64.

Susanna, A. (2007). The weak language learner: a study of ways of taking weak language learners into consideration in class. Sweden: Vaxjo University,School of Humanities English, GIX115.

Thang, S. M., Thing Siew, L., \& Nurjanah Mohd, J. (2011). Attitudes and motivation of Malaysian secondary students towards learning English as a second language: a case study. 


\section{Macrothink \\ International Journal of English Language Education \\ ISSN 2325-0887 2013, Vol. 1, No. 1}

The Southeast Asian Journal of English Language Studies, 17(1), 40-54.

Ting, L. (2009). Language learning strategies -- the theoretical framework and some suggestions for learner training practice. English Language Teaching, 2(4), 199-206.

Trawiński, M. (2005). An Outline of Second Language Acquisition Theories. Wydawnictwo Naukowe Akademii Pedagogicznej.

Wozniak, S. (2010). The language needs analysis from a perspective of international professional mobility: The case of French mountain guides. English For Specific Purposes, 29(4), 243-252. http://dx.doi.org/10.1016/j.esp.2010.06.001

$\mathrm{Wu}, \mathrm{X}$. (2003). Intrinsic motivation and young language learners: the impact of the classroom environment. System, 31(4), 501-517. http://dx.doi.org/10.1016/j.system.2003.04.001

Zhou, H. (2012). Enhancing Non-English Majors' EFL Motivation through Cooperative Learning. Procedia Environmental Sciences, 12, Part B(0), 1317-1323. http://dx.doi.org/10.1016/j.proenv.2012.01.428

\section{Copyright Disclaimer}

Copyright reserved by the author(s).

This article is an open-access article distributed under the terms and conditions of the Creative Commons Attribution license (http://creativecommons.org/licenses/by/3.0/). 